\title{
Wpływ procesów globalizacji i integracji europejskiej na przekształcenia struktur polskiego przemysłu cukrowniczego
}

Problematyka transformacji gospodarki, a w szczególności przekształcania struktur przemysłu w obliczu postępującego procesu umiędzynarodowienia działalności gospodarczej oraz nasilającej się integracji europejskiej, nabiera szczególnego znaczenia. Proces restrukturyzacji, który jest efektem przede wszystkim procesu globalizacji, odgrywa ogromną rolę w unowocześnianiu gospodarki, dlatego też wymaga precyzyjnego rozpoznania mechanizmów jego funkcjonowania oraz identyfikacji i wykorzystania tychże mechanizmów w procesie dostosowania gospodarki kraju do nowych konkurencyjnych warunków gospodarki światowej. Działania te są niezbędne dla zwiększenia konkurencyjności wytwarzanych produktów czy oferowanych usług.

W polskiej literaturze przedmiotu pojęcie restrukturyzacji pojawiło się wraz z zapoczątkowaniem okresu przechodzenia od gospodarki centralnie sterowanej do gospodarki opartej na zasadach rynkowych, gdy wraz ze środkami pomocowymi dotarły do kraju także pewne pakiety programów mających na celu pomoc w uzdrowieniu polskiej gospodarki, a zwłaszcza przedsiębiorstw przemysłowych. Autorzy zajmujący się problematyką restrukturyzacji podejmowali próbę sprecyzowania pojęcia, jednak najczęściej przedstawiane definicje restrukturyzacji były definicjami restrukturyzacji naprawczej. Przedstawiają one istotę procesu, opisują cel i zakres działań restrukturyzacyjnych oraz wyodrębniają poszczególne dziedziny funkcjonowania przedsiębiorstwa.

Według Sapijaszki (1997) restrukturyzacja to radykalna zmiana w co najmniej jednym spośród trzech wymiarów organizacji, tj. zakresie działania, strukturze kapitałowej lub organizacji wewnętrznej firmy. Jej celem jest przywrócenie przedsiębiorstwu równowagi wewnętrznej i równowagi z otoczeniem. Podobnie sformułował pojęcie restrukturyzacji Nalepka (1998), który przyjął, że restrukturyzacja oznacza przemyślaną reorientację celów (misji) przedsiębiorstwa stosownie do zaszłych lub mających zajść w przyszłości zmian w otoczeniu i przystosowanie do tego techniki, organizacji, ekonomiki i kadr.

W literaturze poświęconej tej problematyce można znaleźć wiele definicji restrukturyzacji, które akcentują różne jej cechy, brak jest jednak jednej, która byłaby szeroko akceptowana (Sadzikowski 1989; Jasiński 1992; Kamela-Sowińska, Marecki 1992; Jagoda, Lichtarski 1994; Stabryła 1995; Czapiewski, Kreft 1996; Durlik 1998; Suszyński 1999; Borowiecki 2002).

Restrukturyzacja przedsiębiorstwa traktowana powinna być jako postępowanie diagnostyczno-projektowe usprawniające system zarządzania i system wykonawczy (eksploata- 
cyjny) przedsiębiorstwa pod kątem maksymalnego uwzględnienia uwarunkowań otoczenia i wykorzystania posiadanego potencjału na określonym poziomie (Nalepka 1998).

Wobec powyższego stwierdzenia w niniejszym artykule przyjęto następującą definicję: restrukturyzacja przedsiębiorstwa, ,[...] to proces ciagły zmierzający do zwiększenia efektywności funkcjonowania przedsiębiorstwa w zakresie: produkcji i/lub świadczenia usług, zarządzania i organizacji wewnętrznej, racjonalnego gospodarowania środkami finansowymi oraz kształtowania wizerunku przedsiębiorstwa w otoczeniu, którego celem jest podniesienie bądź utrzymanie pozycji konkurencyjnej przedsiębiorstwa na rynku" (Niemczak 2006).

W zaproponowanej definicji szczególny nacisk położono na rolę pozycji konkurencyjnej. Działania restrukturyzacyjne nie dotyczą jedynie przedsiębiorstw o słabej kondycji gospodarczej bądź zagrożonych upadkiem, ale są także udziałem wiodących przedsiębiorstw poszczególnych gałęzi gospodarki światowej. W szczególny sposób dotyczy to przedsiębiorstw przemysłu wysokich technologii, dla których ciągłe wdrażanie najnowocześniejszych zdobyczy nauki oraz techniki jest równoznaczne z utrzymaniem bądź osiągnięciem pozycji lidera w globalnym systemie gospodarczym.

Restrukturyzacja przedsiębiorstwa jest zatem zmianą o charakterze radykalnym, która reorganizuje przedsiębiorstwo tak, aby wprowadzone zmiany odpowiadały wytyczonym celom oraz były odpowiedzią na sygnały płynące $\mathrm{z}$ otoczenia. W ten sposób przedsiębiorstwa przemysłowe, w tym także przedsiębiorstwa przemysłu cukrowniczego, będą w stanie funkcjonować, rozwijać się i stawać konkurencyjne w dobie postępującego procesu globalizacji działalności gospodarczej i nasilającej się integracji europejskiej.

Kształtujące się obecnie coraz bardziej złożone struktury przemysłowo-kapitałowe wpływają w zasadniczy sposób na nasilające się procesy globalizacji, a także związane $\mathrm{z}$ nimi procesy integracji europejskiej. Znacząca rolę w tym zakresie odgrywają przedsiębiorstwa przemysłowe, spełniające w przestrzeni społeczno-gospodarczej różnorodne funkcje (od światowych, poprzez krajowe, regionalne, po lokalne), między którymi coraz bardziej nasilają się powiązania przestrzenno-produkcyjne. Motorem inicjującym te niezwykle złożone procesy jest nasilająca się konkurencja, poszukiwania coraz rozleglejszych rynków zbytu na określone produkty, począwszy od rynków lokalnych, poprzez rynki regionalne, krajowe, po rynki europejskie i rynek światowy (Zioło, Rachwał 2006).

$\mathrm{W}$ procesie nasilającej się globalizacji podstawową rolę odgrywają wiodące korporacje, które poprzez różnorodne systemy sieciowych powiązań przestrzenno-produkcyjnych organizują światową przestrzeń gospodarczą zgodnie ze swoimi regułami rozwoju (Zioło 2006).

W świetle powyższych przesłanek w niniejszym artykule zmierzano do określenia przemian w wybranych strukturach polskiego przemysłu cukrowniczego, będących następstwem procesów globalizacji i integracji europejskiej, wpływających na transformację uwarunkowań jego funkcjonowania. Szczególny nacisk położono na przekształcenia w strukturze przestrzennej oraz w strukturze własności polskiego przemysłu cukrowniczego w okresie przechodzenia od gospodarki centralnie sterowanej do gospodarki rynkowej. Przedstawiono także znaczenie polskiego przemysłu cukrowniczego na tle cukrownictwa światowego oraz europejskiego. Przekształcenia w polskim cukrownictwie są wynikiem postępującego procesu globalizacji i integracji europejskiej, który wyrażał się w podjętych działaniach restrukturyzacyjnych. Wyrazem podjęcia tych działań jest proces koncentracji produkcji i kapitału zapoczątkowany w 2001 roku i sukcesywnie realizowany do dzisiaj. 


\section{PolsKi PRZEMYSŁ CUKROWNICZY A GLOBALIZACJA}

Podejmując problematykę kształtowania się przedsiębiorstw przemysłowych w procesie globalizacji wstępnie przyjmujemy, że każda firma prowadzi działalność gospodarczą czy usługową w celu osiagnięcia maksymalnego zysku (obecnie czy też w przyszłości). Do osiagnięcia tego celu zmierza poprzez rozwijanie działalności gospodarczej w zależności od zasobów kapitałowych, możliwości produkcyjnych oraz pozycji na rynku (światowym, kontynentalnym, krajowym, regionalnym czy lokalnym), dążąc do coraz lepszego zaspokajania potrzeb i oczekiwań konsumentów. Działaniom tego typu towarzyszą tendencje do stałego podnoszenia produktywności przez wykorzystywanie istniejących zasobów produkcyjnych będących do dyspozycji przedsiębiorstwa (Zioło 2003).

Przemiany uwarunkowań funkcjonowania przemysłu cukrowniczego w Polsce w okresie przechodzenia od gospodarki centralnie sterowanej do gospodarki rynkowej oprócz aspektu przemian ustrojowych szczególnie uzależnione były od postępującego procesu globalizacji działalności gospodarczej oraz nasilającej się integracji europejskiej. Proces ten jest bardziej zaawansowanym procesem umiędzynarodowienia działalności gospodarczej a traktowany jest jako rozszerzenie działalności gospodarczej ponad granicami państw. W procesie globalizacji istotne znaczenie ma szereg elementów, jednakże do najważniejszych z nich należą integracja, powiązania czy współzależność.

Jednym z widocznych efektów postępującego procesu globalizacji i integracji europejskiej jest proces koncentracji kapitału, który prowadzi do uściślania powiązań pomiędzy przedsiębiorstwami działającymi na rynku międzynarodowym. Korporacje ponadnarodowe posiadają znacznie większe zasoby kapitałowe, dysponują zdecydowanie nowocześniejszym zapleczem technologicznym i badawczym, a ich zdolności i moce produkcyjne także są zdecydowanie większe, dlatego też stają się głównymi podmiotami kształtującymi procesy gospodarcze.

Według Zioło (2003) w procesie globalizacji działalności gospodarczej i tworzenia się ponadnarodowych korporacji przemysłowych, kapitałowych czy handlowych szczególnie ważną rolę $\mathrm{w}$ procesach rozwojowych przedsiębiorstw odgrywają powiązania międzynarodowe. Mogą one działać jako czynniki pobudzające rozwój działalności produkcyjnej lub stwarzać bariery hamujące ich rozwój.

Funkcjonowanie polskiego przemysłu cukrowniczego w okresie przechodzenia od gospodarowania centralnie sterowanego do gospodarowania opartego na zasadach rynkowych uzależnione było od aktualnych uwarunkowań społeczno-gospodarczych oraz politycznych. Ponieważ transformacja gospodarki, a w szczególności restrukturyzacja przedsiębiorstw jest ściśle powiązana z dużymi nakładami finansowymi oraz zmianą systemów zarządzania (Stabryła 2000), miało to wpływ na przebieg przekształceń w strukturze przestrzennej przemysłu cukrowniczego w Polsce, głównie tempa procesu koncentracji produkcji w poszczególnych koncernach producenckich.

W latach 2001-2006 liczba cukrowni w polskim przemyśle cukrowniczym zmniejszyła się z 76 do 36, czyli zlikwidowano 40 cukrowni stanowiących 52,6\% stanu z roku 2000. Najważniejszymi determinantami tej redukcji były m.in.: liczba cukrowni w danym województwie, ich możliwości przerobowe i produkcyjne, wyniki finansowe oraz dogodne powiązania komunikacyjne. Wymienione czynniki nakładając się na siebie powodowały, że produkcję przejęły cukrownie o najlepszych wynikach techniczno-produkcyjnych oraz finansowych (Niemczak 2007). 


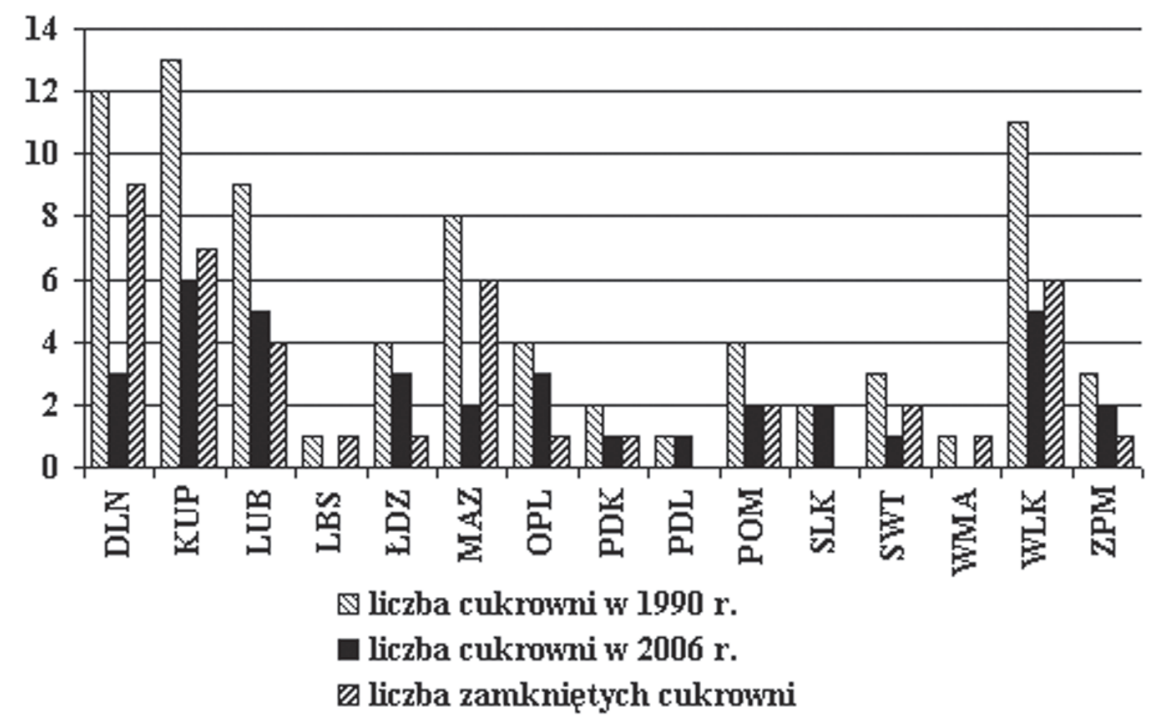

Ryc. 1. Zmiany liczby cukrowni w Polsce w latach 1990-2006 według województw

Źródło: opracowanie własne na podstawie Niemczak 2007

Wynikiem procesu restrukturyzacji poprzez koncentrację jest regionalizacja procesu produkcji przez koncern Pfeifer \& Langen wyłącznie na terenie województwa wielkopolskiego. Dwa koncerny zredukowały liczbę cukrowni do dwóch, natomiast w Krajowej Spółce Cukrowej oraz Südzucker Polska trzon produkcyjny stanowią największe a zarazem najmłodsze cukrownie: Ropczyce (1979), Krasnystaw (1976), Łapy (1974) i Werbkowice (1963).

Tab. 1. Struktura własności cukrowni w Polsce według koncernów w $2006 \mathrm{r}$. oraz produkcja cukru w tonach w kampanii cukrowniczej 2006/2007

\begin{tabular}{|l|c|c|c|c|}
\hline \multirow{2}{*}{\multicolumn{1}{|c|}{ Koncern }} & \multicolumn{3}{|c|}{ Liczba cukrowni } & \multirow{2}{*}{$\begin{array}{c}\text { Produkcja } \\
\text { cukru (t) }\end{array}$} \\
\cline { 2 - 5 } & ogółem & aktywnych & zamkniętych & 208121 \\
\hline BSO Polska & 10 & 2 & 8 & 637451 \\
\hline KSC Polski Cukier & 27 & 18 & 9 & 142000 \\
\hline Nordzucker Polska & 6 & 2 & 4 & 285673 \\
\hline Pfeifer \& Langen & 11 & 4 & 7 & 447107 \\
\hline Südzucker & 22 & 10 & 12 & 1720352 \\
\hline OGÓŁEM & 76 & 36 & 40 & \\
\hline
\end{tabular}

Źródło: opracowanie własne na podstawie Niemczak 2007 oraz ZPC 
Przemysł cukrowniczy w Polsce zdominowany jest przez kapitał zagraniczny. Cztery koncerny zagraniczne dysponujące w 2006 r. połową czynnych cukrowni wytworzyły w kampanii cukrowniczej 2006/2007 łącznie 62,9\% ogółu krajowej produkcji cukru (1 082901 ton). Wartość rocznej sprzedaży przemysłu cukrowniczego szacowana jest na ok. 1\% wartości sprzedaży ogółu przemysłu przetwórczego w Polsce. Wynika z tego, że koncerny zagraniczne dysponują kwotą ponad 2 mld złotych rocznie z tytułu przychodów ze sprzedaży. Koncerny zagraniczne cechują się zdecydowanie korzystniejszymi wartościami podstawowych danych przerobowych. Dotyczy to szczególnie globalnej produkcji cukru przypadającej na jedną cukrownię koncernu. Wskaźniki te świadczą o wyższym poziomie technicznym i technologicznym produkcji, większej wydajności pracy oraz bardziej racjonalnym zarządzaniu i gospodarowaniu dostępnymi środkami.

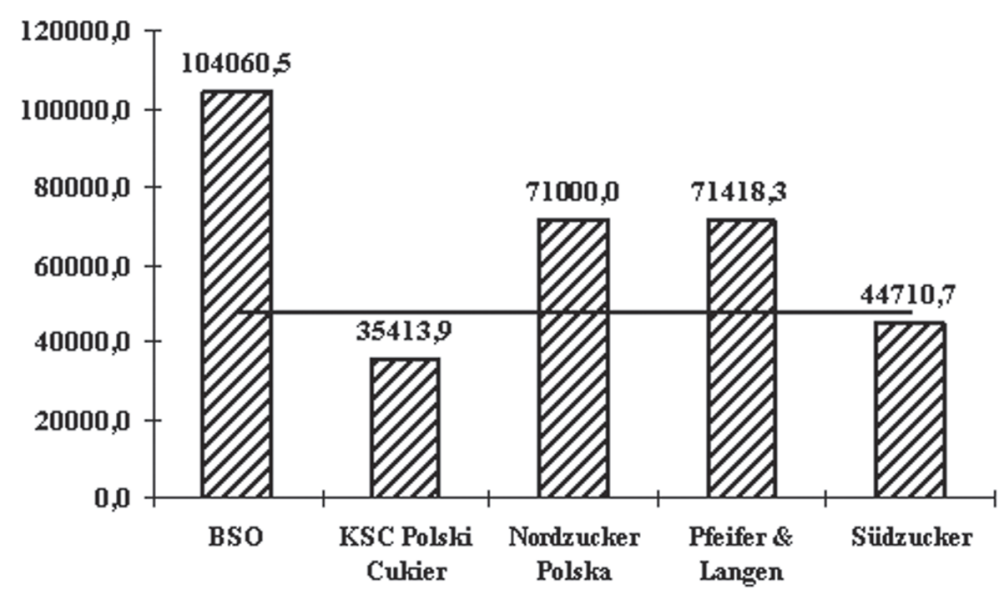

Ryc. 2. Produkcja cukru w Polsce w kampanii 2006/2007

$\mathrm{w}$ tonach/cukrownie w poszczególnych koncernach

Źródło: opracowanie własne na podstawie Niemczak 2007 oraz ZPC

Podczas kampanii cukrowniczej 2006/2007 średnia krajowa produkcja cukru przypadająca na jedną cukrownię wynosiła 47 787,6 tony. W przypadku dwóch koncernów (Krajowej Spółki Cukrowej oraz Südzucker) była ona wyższa od średniej dla tych koncernów, natomiast w trzech pozostałych koncernach zdecydowanie produkcja była wyższa od średniej krajowej (ryc. 2).

Najlepszym pod tym względem był koncern BSO Polska, w którym średnio jedna cukrownia wyprodukowała ponad 104 tys. ton cukru. Wynik tego koncernu nie jest zaskoczeniem, ponieważ BSO jako pierwsze rozpoczęło na szeroką skalę proces restrukturyzacji oraz posiada największą, najmłodszą (1984) oraz najnowocześniejszą cukrownię w Polsce, której możliwości produkcyjne oceniane są na ok. 150 tys. ton - czyli prawie 1/12 rocznej krajowej produkcji cukru. Dwa pozostałe koncerny: Nordzucker Polska oraz Pfeifer \& Langen wyprodukowały średnio w jednej cukrowni ok. 71 tys. ton cukru. Różnica pomiędzy BSO Polska a krajowym producentem jest bardzo wyraźna na niekorzyść Krajowej Spółki Cukrowej, w której jedna cukrownia w trakcie kampanii 2006/2007 wyprodukowała ok. 1/3 średniej produkcji cukrowni BSO. 
W ostatnim roku na funkcjonowanie przemysłu cukrowniczego nie tylko w Polsce, ale i w całej Unii Europejskiej niewątpliwie wpływ wywarło i będzie wywierać Rozporządzenie Rady (WE) NR 318/2006 w sprawie wspólnej organizacji rynków w sektorze cukru, z dnia 20 lutego 2006 r., z późniejszymi zmianami.

Produkcja cukru w Unii Europejskiej była wyższa od jego spożycia, co powodowało duże trudności z magazynowaniem i późniejszym wykorzystaniem. Aby przeciwdziałać tej niekorzystnej sytuacji, wprowadzono regulacje prawne w tym zakresie. Określono limity produkcji dla poszczególnych krajów, wyznaczono ceny preferencyjne dla cukru i buraków cukrowych (systematycznie malejące), a także określono przeznaczenie nadprodukcji cukru.

Produkcja cukru w Unii Europejskiej została określona na 16599138 ton. Dla każdego z krajów członkowskich rozporządzenie to zawiera limit produkcji. Polsce limit produkcji cukru został wyznaczony na 1772477 ton, co czyni Polskę trzecim producentem cukru w Europie. Według artykułu 7 ust. 2. omawianego rozporządzenia ,[...] państwa członkowskie przydzielają kwotę każdemu przedsiębiorstwu produkującemu cukier, prowadzącemu działalność na jego terytorium". W Polsce limity produkcji cukru zostały przydzielone pomiędzy poszczególne koncerny zgodnie z ich udziałami w rynku. Najwięcej otrzymała Krajowa Spółka Cukrowa (prawie 40\%), następnie Südzucker (ponad 25\%), Pfeifer \& Langen (prawie 16\%), BSO Polska (ponad 10\%), natomiast najmniej Nordzucker (niecałe 9\%). Oczywiście samo określenie limitów produkcji cukru nie jest wystarczające dla efektywnego kontrolowania ilości wytwarzanego surowca, stąd rozporządzenie to przewiduje także możliwości wykorzystania cukru z nadprodukcji oraz określone sankcje. Według artykułu 12 ,[...] cukier wyprodukowany w roku gospodarczym w ilości przekraczającej limit, może być między innymi: przeniesiony na kolejny rok lub użyty do przetworzenia pewnych produktów”. W treści art. 13. do tych ,pewnych produktów” zaliczono między innymi: bioetanol, rum czy żywe kultury drożdży. Oprócz tego nadprodukowany cukier może być wykorzystany do produkcji ,[...] pewnych produktów przemysłowych niezawierających cukru, do przetworzenia których używa się cukru, lub pewnych produktów chemicznych lub farmaceutycznych zawierających cukier".

Ceny referencyjne określone w rozporządzeniu systematycznie maleją. Cena referencyjna na cukier (niepakowany) spadnie z 631,9 euro za tonę w okresie kampanii cukrowniczej 2007/2008 do 404,4 euro w kampanii 2009/2010. Podobnie będzie w przypadku ceny referencyjnej na buraki cukrowe, która w analogicznym okresie spadnie z 29,78 do 26,29 euro za tonę.

Polska po wejściu do Unii Europejskiej stała się bezpośrednim beneficjentem praw i obowiązków wynikających z członkostwa. Stąd postępujący proces globalizacji i integracji europejskiej ma niebagatelne znaczenie dla funkcjonowania przemysłu cukrowniczego w Polsce

\section{POLSKI PRZEMYSŁ CUKROWNICZY NA ARENIE MIĘDZYNARODOWEJ}

Przemysł cukrowniczy na świecie, w odróżnieniu od europejskiego, opiera się przede wszystkim na przerobie trzciny cukrowej, z której wytwarza się około 80\% ogółu światowej produkcji cukru.

Według danych Międzynarodowej Organizacji Cukru, w bieżącym roku (2007) największym producentem cukru na świecie zostaną Indie, które z produkcją wynoszącą 
ok. 33 mln ton wyprzedzą dotychczasowego lidera, jakim była Brazylia, która w tym samym okresie wyprodukuje szacunkowo $32 \mathrm{mln}$ ton cukru. Należy jednak tutaj zaznaczyć, że Brazylia dodatkowo produkuje $22 \mathrm{mln}$ ton rocznie z przeznaczeniem na bioetanol, w związku z tym całkowita produkcja Brazylii wynosić będzie $54 \mathrm{mln}$ ton.

Powodem tak dużego wzrostu produkcji cukru w Indiach są między innymi sprzyjające warunki klimatyczne panujące w 2007 roku (pora monsunu) oraz subwencje państwowe do produkcji trzciny cukrowej z gwarantowanymi cenami obowiązującymi na rok 2007/2008. Przypuszczalnie jednak w latach następnych gwarantowane ceny nie zostaną utrzymane, w związku z powyższym wiodące znaczenie Indii może rychło się skończyć. Wysoka tegoroczna produkcja w Indiach przyczyni się do eksportu cukru na poziomie ok. $5 \mathrm{mln}$ ton.

Przemysł cukrowniczy w Unii Europejskiej z roczną produkcja prawie $17 \mathrm{mln}$ ton nie ma większego znaczenia w ujęciu globalnym. Zwłaszcza że cukrownictwo europejskie oparte jest prawie wyłącznie na buraku cukrowym. Pozyskiwanie cukru z tego surowca jest kosztowniejsze niż z trzciny cukrowej, co dodatkowo tworzy niekorzystną sytuację. Stąd różnorodne zabiegi zmierzające do ochrony miejscowych producentów cukru, jak i mechanizmy i finansowe instrumenty wspierające i zachęcające do przekwalifikowania profilu działalności.

Tab. 2. Limity produkcji cukru w Unii Europejskiej w tonach w według państw członkowskich lub regionów

\begin{tabular}{|l|c|}
\hline \multicolumn{1}{|c|}{ Państwo } & Limit produkcji \\
\hline Belgia & $862.077,0$ \\
\hline Bułgaria & $4.752,0$ \\
\hline Czechy & $367.937,8$ \\
\hline Dania & $420.746,0$ \\
\hline Niemcy & $3.655 .455,5$ \\
\hline Irlandia & 0 \\
\hline Grecja & $158.702,0$ \\
\hline Hiszpania & $887.163,7$ \\
\hline Francja & $3.640 .441,9$ \\
\hline Francuskie departamenty zamorskie & $480.244,5$ \\
\hline Włochy & $753.845,5$ \\
\hline Łotwa & 0 \\
\hline Litwa & $103.010,0$ \\
\hline Węgry & $298.591,0$ \\
\hline Holandia & $876.560,0$ \\
\hline Austria & $405.812,4$ \\
\hline Polska & $\mathbf{1 . 7 7 2 . 4 7 7 , 0}$ \\
\hline Portugalia (kontynentalna) & $15.000,0$ \\
\hline Autonomiczny Region Azorów & $9.953,0$ \\
\hline Rumunia & 109.164 \\
\hline Słowenia & 0 \\
\hline Słowacja & $140.031,0$ \\
\hline Finlandia & $90.000,0$ \\
\hline Szwecja & $325.700,0$ \\
\hline Wlk. Brytania & $1.221 .474,0$ \\
\hline OGÓŁEM & $16.599 .138,3$ \\
\hline
\end{tabular}


Biorąc pod uwagę tylko rynek europejski, Polska jest trzecim producentem cukru, a ustępuje jedynie Niemcom oraz Francji (ponad 22\% każde). Kraje te łącznie produkują blisko 55\% cukru w Europie, z czego na Polskę przypada ponad 10,5\% produkcji.

Jednakże zwracając uwagę na poziom techniczny i technologiczny procesu produkcji oraz wartości wskaźników podstawowych danych przerobowych (produkcja cukru przypadająca na jedną cukrownię, dobowy przerób buraków cukrowych itp.), polski przemysł cukrowniczy (nie będący we władaniu koncernów zachodnioeuropejskich, czyli Krajowa Spółka Cukrowa) jest w stosunkowo złej sytuacji.

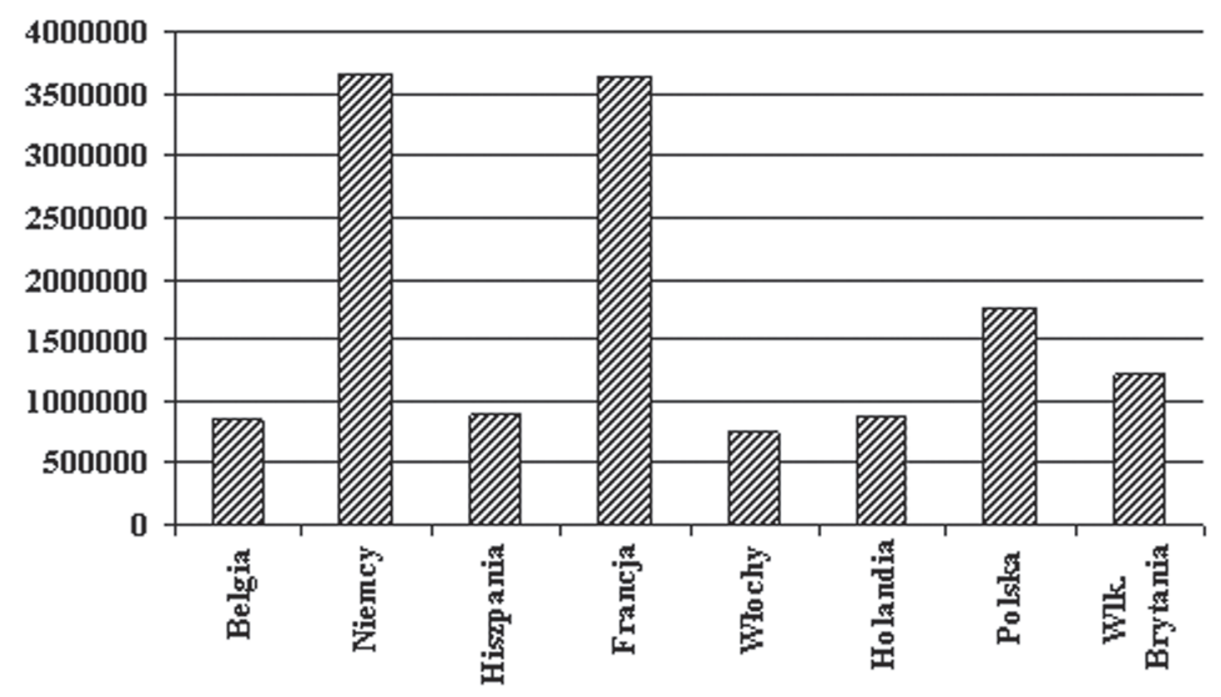

Ryc. 3. Limity produkcji cukru w tonach w wybranych krajach Unii Europejskiej

Źródło: dane tabela nr 2

\section{Podsumowanie}

Wpływ postępującego procesu globalizacji i nasilającej się integracji europejskiej na funkcjonowanie i przekształcanie struktur polskiego przemysłu cukrowniczego jest bardzo wyraźny. Z jednej strony proces tworzenia się ,globalnej wioski” niejako wymusza na przedsiębiorstwach działania zmierzające do podniesienia zaawansowania technicznego i technologicznego procesu produkcji, z drugiej zaś nasilająca się integracja europejska stwarza określone bariery i ograniczenia prawne. Jednak efekt obydwu zjawisk jest ten sam. Przetrwają na europejskim rynku produkcji cukru dominujący producenci, dysponujący największymi zasobami finansowymi i intelektualnymi oraz posiadający najbardziej zaawansowane technicznie i technologiczne zaplecze produkcyjne.

Bardzo ograniczone własne zasoby kapitałowo-finansowe przedsiębiorstw, które można przeznaczyć na ich modernizację i podniesienie pozycji konkurencyjnej na rynku, wynikały w dużej mierze z wdrażania mechanizmów prywatyzacji w Polsce. Początkowo objęły one 
przedsiębiorstwa najbardziej efektywnie działające na rynku i miały głównie na celu dostarczenie określonych środków finansowych do budżetu krajowego, a nie zasilenie kapitałowe procesów restrukturyzacji. Najmniej efektywne przedsiębiorstwa nie znajdowały nabywcy lub ograniczano w nich proces prywatyzacji ze względów politycznych. Pozostałe w nich silne struktury ruchu związkowego w zasadniczym stopniu ograniczały możliwości działań restrukturyzacyjnych (Poznański 2001).

Wpływ globalizacji i integracji europejskiej na funkcjonowanie i przekształcanie struktur polskiego cukrownictwa jest bardzo wyraźny. Z jednej strony proces tworzenia się „globalnej wioski” niejako wymusza na przedsiębiorstwach działania zmierzające do podnoszenia zaawansowania technicznego i technologicznego procesu produkcji, z drugiej zaś integracja europejska stwarza określone bariery i ograniczenia prawne.

Reforma systemu regulacji rynku cukru będzie miała duży wpływ na sytuację w UE. Zdecyduje o tym przede wszystkim zmniejszenie kwot produkcyjnych oraz redukcja cen. Cena referencyjna na cukier spadnie z aktualnych 631,9 euro za tonę do 404,4 w kampanii 2009/2010. Podobnie będzie w przypadku ceny referencyjnej na buraki cukrowe, która spadnie z 29,78 do 26,29 euro za tonę.

Założonym przez Komisję celem reformy jest poprawa konkurencyjności sektora cukrowniczego, która wymusi jego restrukturyzację na poziomie rolnictwa i przemysłu. Skutki zmian w systemie regulacji będą zatem różne w poszczególnych krajach członkowskich ze względu na duże zróżnicowanie kosztów produkcji oraz warunków naturalnych. Nie ulega wątpliwości, iż nowe regulacje będą miały decydujący wpływ na warunki funkcjonowania polskiego przemysłu cukrowniczego. Na europejskim i polskim rynku cukru pozostaną tylko dominujący producenci dysponujący największymi zasobami finansowymi $\mathrm{i}$ intelektualnymi oraz posiadający najbardziej zaawansowane technicznie i technologicznie zaplecze produkcyjne.

\section{Literatura}

Borowiecki R., 2002, Dylematy zarzqdzania restrukturyzacja przedsiębiorstw w warunkach transformacji systemowej w Polsce, [w:] Gospodarka Polski na przełomie wieków, red. Z. Dach, PTE, Kraków

Czapiewski M., Kreft Z., 1996, Koncepcja restrukturyzacji Portu Handlowego Gdynia S.A., [w:] Restrukturyzacja przedsiębiorstw w procesie transformacji rynkowej, Materiały z ogólnopolskiej konferencji naukowej, oprac. i red. naukowa R. Borowiecki, AE-TNOiK, Kraków

Durlik I., 1998, Restrukturyzacja procesów gospodarczych. Reengineering. Teoria i praktyka, Agencja Wydawnicza „Placet”, Warszawa

Jagoda H., Lichtarski J., 1994, Problemy $i$ wytyczne restrukturyzacji naprawczej przedsiębiorstw, [w:] Restrukturyzacja przedsiębiorstw w procesie transformacji systemowej, red. R. Borowiecki, AE-TNOiK, Kraków

Jasiński Z., 1992, Restrukturyzacja systemu zarzqdzania przedsiębiorstwem, „Ekonomika i Organizacja Przedsiębiorstwa" nr 8

Kamela-Sowińska A., Marecki A. B., 1992, Niezbędne indywidualne podejście, „Rzeczpospolita” z 19 VIII

Nalepka A., 1998, Zarys problematyki restrukturyzacji przemystu, Antykwa, Kraków-Kluczbork

Niemczak M., 2006, Restrukturyzacja przemystu cukrowniczego w Polsce, Praca magisterska wykonana w Zakładzie Przedsiębiorczości i Gospodarki Przestrzennej, Instytut Geografii AP w Krakowie pod kierunkiem prof. Zbigniewa Zioło 
Niemczak M., 2008, Przemiany struktur polskiego przemystu cukrowniczego jako efekt procesu restrukturyzacji, Procesy transformacji układów przemystu na tle zmieniajacego się otoczenia, Prace Komisji Geografii Przemysłu PTG, nr 10, Warszawa-Kraków

Poznański K., 2001, Wielki przekręt. Klęska polskich reform, Olsztyn

Rozporządzenie Rady (WE) NR 318/2006

Sadzikowski W., 1989, Finansowanie procesu restrukturyzacji przemystu w Polsce, „Finanse”, nr 1

Sapijaszka Z., 1997, Restrukturyzacja przedsiębiorstwa. Szanse i zagrożenia, PWN, Warszawa

Stabryła A., 1995, Zarzqdzanie rozwojem firmy, Księgarnia Akademicka, Kraków

Stabryła A., red., 2000, Strategie wzrostu produktywności firmy, Kraków

Suszyński C., 1999, Restrukturyzacja przedsiębiorstw. Proces zarzadzania zmianami, PWE, Warszawa

Zaorska A., 1998, Ku globalizacji? Przemiany w korporacjach transnarodowych $i$ w gospodarce światowej, Wydawnictwo Naukowe PWN, Warszawa

Zioło Z., 2003, Ksztaltowanie się przedsiębiorstw przemystowych w procesie globalizacji, Prace Komisji Geografii Przemysłu PTG, nr 6, Warszawa-Kraków

Zioło Z., Rachwał T., 2006, Wprowadzenie, [w:] Międzynarodowe uwarunkowania rozwoju przemystu, Prace Komisji Geografii Przemysłu PTG, nr 8, Warszawa-Kraków

Zioło Z., 2006, Zróżnicowanie światowej przestrzeni przemysłowej w świetle koncentracji siedzib zarzqdów wiodacych korporacji, Prace Komisji Geografii Przemysłu PTG, nr 8, Warszawa-Kraków

\section{Influence of globalization and European integration processes on structural transformations in the Polish sugar industry}

The problem of economic transformation, and especially of structural transformations of industries in view of globalization and European integration becomes particularly significant. One of the most important effects of globalization, vital in modernization of economy, is restructuring of industry. This process requires precise recognition of the mechanisms of its functioning and identification and employment of these mechanisms in the process of adapting countries' economies to the new, competitive conditions of the global economy.Such actions are indispensable to increase the competitiveness of products and services provided by enterprises.

In the period of transformation, functioning of the Polish sugar industry depended not only on the current socio-economic conditions, but also on the influence of integration processes. As economic transformation, especially restructuring of enterprises, is strictly connected with great financial expenditure and with changes in the system of management, it had an effect on the course of transformations in the spatial structure of the Polish sugar industry. 